\title{
17 $\beta$-Carboxamide Steroids: Highly Effective Inhibitors of the Phytohaemagglutinin Mediated Blastogenesis of Normal Human Peripheral Lymphocytes
}

\author{
By B. Manz, Marianne Rehder, A. Heubner, R. Kreienberg, H.-J. Grill and K. Pollow \\ Abteilung für Experimentelle Endokrinologie (Leiter: Prof. Dr. K. Pollow), \\ Johannes Gutenberg Universität Mainz
}

(Received August 1/ December 13, 1983)

\begin{abstract}
Summary: Several novel 17 $\beta$-carboxamide analogues of dexamethasone were synthesized. The common precursor, 9-fluoro-16 $\alpha$-methyl-11 $\beta, 17$-dihydroxy-3-oxo-1,4-androstadiene-17 $\beta$-carboxylic acid, did not bind to the glucocorticoid receptors of rat liver and human spleen tumours. In addition, no inhibition of the mitogen-induced blastogenesis of cultured human peripheral lymphocytes was observed. The $17 \beta$-carboxamide analogues, however, bound with similar affinities to the glucocorticoid receptors of both tissues. They inhibited the mitogen-induced blastogenesis of peripheral lymphocytes, showing the same potency and same order of binding affinity as the natural glucocorticoids.
\end{abstract}

17ß-Carboxamid-Steroide: Hochwirksame Inhibitoren der phytohämagglutinin-induzierten Blastogenese normaler peripherer menschlicher Lymphocyten

Zusammenfassung: Es wurden mehrere neuartige $17 \beta$-Carboxamid-Analoga des Dexamethasons synthetisiert. Die Ausgangsverbindung, 9-Fluor-16 $\alpha$-methyl-11ß,17-dihydroxy-3-oxo-1,4-androstadien-17 $\beta$-carbonsäure, zeigte keine Bindung an Rattenleber- oder menschliche Milztumor-Glucocorticoidrezeptoren. Ėbenso konnte keine Inhibition der mitogen-induzierten Blastogenese normaler menschlicher Lymphocyten gežeigt werden. Im Gegensatz dazu banden die 17ß-Carboxamid-Analoga mit ähnlicher Affinität an die Glucocorticoidrezeptoren beider Gewebe. Ihre Potenz, die mitogen-induzierte Blastogenese der Lymphocyten zu hemmen, war von der natürlicher Glucocorticoide nicht zu unterscheiden und korrespondierte mit der jeweiligen Affinität zum Rezeptor.

\section{Introdüction}

Antagonists of steroid activity are useful probes for understanding both the role of steroids in vivo and their mechanism of action $(1,2)$. While it is known that many characteristic hormonal responses of steroids are contingent upon their binding to specific receptors in target tissue, a detailed understanding of the steps (receptor activation, translocation, interaction with cell chromatin, etc.) leading to the specific biological effects in the target tissues, is far from complete (3).
The existence of antagonists that compete for the steroid binding site of the receptor with high affinity demonstrate that the phenomena of binding and activity are at least partially independent. Rousseau et. al. (1) previously reported that $17 \beta$-carboxamide analogs of dexamethasone represent a new class of glucocorticoid antagonists. Their antiglucocorticoid effect on rat hepatoma tissue culture cells was dose dependent and the order of potency of the antagonists was consistent with their affinity for the rat hepatoma and rat liver glucocorticoid receptors. 
Recently, we compared the inhibitory effects of synthetic and natural glucocorticoids as well as some of their $17 \beta$-carboxy analogues on the incorporation of radiolabeled thymidine into phytohaemagglutininstimulated human peripheral blood lymphocytes, and obtained the opposite result! The benzyl $17 \beta-$ carboxamide analogue of dexamethasone (compound Ic) behaved like a glucocorticoid agonist and the order of potency of this agonist was consistent with its affinity for human spleen tumour and rat liver receptors (4-7).

In the present study we investigated a larger number of steroids (some of these are new steroids), and showed that $17 \beta$-carboxamide analogues of dexamethasone generally show a dose-dependent glucocorticoid effect on phytohaemagglutinin-stimulated human peripheral lymphocytes.

\section{Materials and Methods}

Hormones and chemicals

$\left[1,2(\mathrm{~N})-{ }^{3} \mathrm{H}\right]$ Dexamethasone $(0.72 \mathrm{TBq} / \mathrm{mmol})$ and $\left[5^{\prime}-{ }^{3} \mathrm{H}\right]$ thymidine $(0.18 \mathrm{TBq} / \mathrm{mmol})$ were generous gifts from Amersham International, Cardiff, England.

Dexamethasone (1) (9-fluoro-16 $\alpha$-methyl-11 $\beta, 17,21$-trihydroxy1,4-pregnadiene-3,20-dione) and betamethasone (II) (9-fluoro$16 \beta$-methyl-11 $\beta, 17,21$-trihydroxy-1,4-pregnadiene-3,20-dione) were purchased from Sigma, München, F.R.G. All other chemicals were of reagent grade.

Analytical and preparative thin-layer chromatography was carried out using precoated silicic acid $F_{254}$ plates (Merck, Darmstadt, F.R.G). Thin-layer plates were developed in the following solvent systems:

(A) chloroform/methanol $9+1$ (by vol.);

(B) ethyl acetate/ethanol/ $\mathrm{NH}_{3} 5+5+1$ (by vol.).
The 17ß-carboxylic acid analogues (Ia; IIa) (see tab. 1) were obtained by periodic acid oxidation. The following $17 \beta$-carboxamide analogues were synthesized according to Formstecher et al. (8):

$\mathrm{N}$-benzyl 9-fluoro-16 $\alpha$-methyl-11 $\beta, 17$-dihydroxy-3-oxo-1,4-androstadiene-17 $\beta$-carboxamide (le; m.p. $258^{\circ} \mathrm{C}$ );

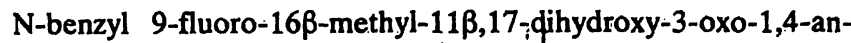
drostadiene-17 $\beta$-carboxamide (IIb; m.p. $250-252^{\circ} \mathrm{C}$ );

$2^{\prime}$-(p-fluoro-16 $\alpha$-methyl-11 $\beta, 17$-dihydroxy-3-oxo-1,4-androstadiene-17. $\beta$-carboxamido)glutaric acid di-tert-butyl ester (Ig; m.p. $215^{\circ} \mathrm{C}$ );

N-propyl 9-fluoro-16 $\alpha$-methyl-11 $\beta, 17$-dihydroxy-3-oxo-1,4-androstadiene-17 $\beta$-carboxamide (Ic; $259-260^{\circ} \mathrm{C}$ );

$\mathrm{N}$-p-azidobenzyl 9-fluoro-16 $\alpha$-methyl-11 $\beta, 17$-dihydroxy-3-oxo1,4 -androstadiene-17 $\beta$-carboxamide (İf; ir $2100 \mathrm{~cm}^{-1}$ (azido)).

The synthesis of $\mathrm{N}$-(2-amino)-ethyl 9-fluoro-16 $\alpha$-methyl-11 $\beta, 17-$ dihydroxy-3-oxo-1,4-androstadiene-17 $\beta$-carboxamide (Ib) and $\mathrm{N}$-(5-amino)-pentyl 9-fluoro-16 $\alpha$-methyl-11 $\beta, 17$-dihydroxy-3oxo-1,4-androstadiene-17 $\beta$-carboxamide (Id) is described elsewhere (9).

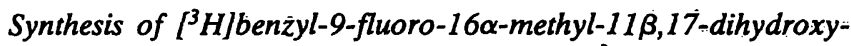
3-oxo-1,4-androstadiene-17 $\beta$-carboxamide $\left(\left[{ }^{3} \mathrm{H}\right] \mathrm{Ie}\right)$

$54 \mathrm{nmol}$ of $\left[{ }^{3} \mathrm{H}\right]$ dexamethasone $(92.5 \mathrm{MBq})$ in $2.5 \mathrm{ml}$ of ethanol was evaporated to dryness in a round bottomed flask and redissolved in $1 \mathrm{ml}$ methanol. Periodic acid solution ( $340 \mathrm{mg}$ periodic acid, $97.5 \mathrm{ml} \mathrm{H}_{2} \mathrm{O}, 0.5 \mathrm{ml}$ of conc. $\left.\mathrm{HCl}\right)(500 \mu \mathrm{l})$ was added and the oxidation was complete within $5 \mathrm{~h}$. The organic solvent was removed under reduced pressure and the acid extracted three times with $5 \mathrm{ml}$ ethyl acetate. The combined organic extracts were evaporated to dryness, and the remaining residue was again dissolved in $200 \mu \mathrm{l}$ methanol and further purified on thin-layer plates in solvent system (B). Identity of the purified acid was confirmed by its $R_{f}$-values on thin-layer plates in solvent system $(A)$ and $(B)$.

To $44.4 \mathrm{MBq}(32 \mathrm{nmol})$ of the purified acid in $1 \mathrm{ml}$ of ethyl acetate, $25 \mu$ l of a solution of dicyclohexylcarbodiimide $(1 \mathrm{~g} / \mathrm{l})$ and $12.5 \mu \mathrm{l}$ of a solution of benzylamine $(1 \mathrm{~g} / \mathrm{l})$ in ethyl acetate were added and the mixture was kept for $36 \mathrm{~h}$ at room temperature. The carboxamide $\left[{ }^{3} \mathrm{H}\right] \mathrm{Ie}$ was purified on' thin-layer plates in solvent system (A) and characterized as described above.

\section{Preparation of homogenates}

Human spleen tumour tissue was stored at $-70^{\circ} \mathrm{C}$ until use. After thawing at $0^{\circ} \mathrm{C}$ in buffer consisting of $200 \mathrm{ml} / \mathrm{l}$ glycerol, $2 \mathrm{mmol} / \mathrm{l}$ $\mathrm{CaCl}_{2}, 1 \mathrm{mmol} / \mathrm{l} \mathrm{MgCl}, 20 \mathrm{mmol} / \mathrm{l}$ Tris- $\mathrm{HCl}(\mathrm{pH} \mathrm{7.4})$ the tissue

Tab. 1. Steroid structures.

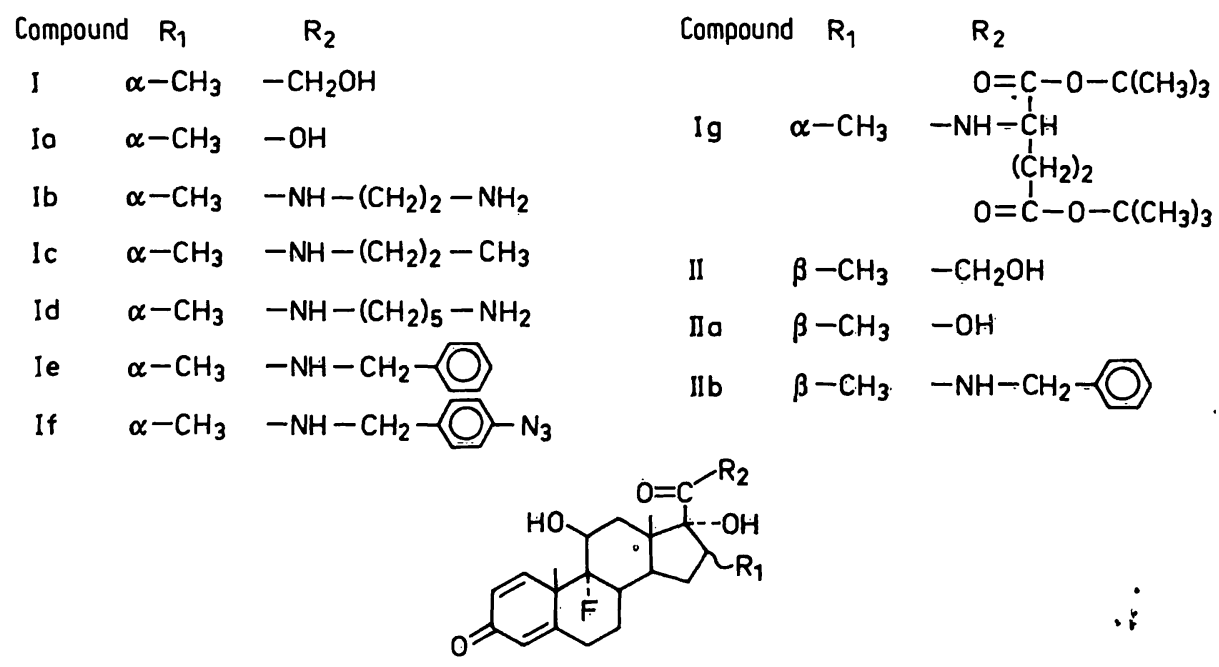


was minced in 3 volumes of buffer and homogenized by 10 strokes in a Potter-Elvehjem homogenizer. The homogenate was centrifuged for $1 \mathrm{~h}$ at $105000 \mathrm{~g}$ and the supernatant taken as cytosol. Male Wistar rats $(\sim 150 \mathrm{~g})$ were bilaterally adrenalectomized and maintained on normal saline for 4 days prior to sacrifice. The livers were perfused with cold buffer and processed as described above.

Protein concentrations were determined with the BioRad protein kit (BioRad, Richmond, USA).

\section{Competition assay}

The tubes were prepared as follows: to each tube $0.1 \mathrm{ml}$ of $\left[{ }^{3} \mathrm{H}\right]$ dexamethasone (in buffer) was pipetted, to give a final concentration of $32 \mathrm{nmol} / \mathrm{l}$. Then aliquots of $0.1 \mathrm{ml}$ of buffer containing the various competitors at 10 different concentrations (3.2-640 nmol/l) were added. Finally, $0.2 \mathrm{ml}$ of cytosol was added to each tube and the tubes were incubated for $4 \mathrm{~h}$ at $0^{\circ} \mathrm{C}$. Incubation was terminated by the addition of $1 \mathrm{ml}$ dextran-coated charcoal suspension. The final concentrations were $5 \mathrm{~g} / \mathrm{l}$ of charcoal and $0.5 \mathrm{~g} / \mathrm{l}$ of dextran $\mathrm{T} 500$. After $10 \mathrm{~min}$ of incubation the tubes were centrifuged for $10 \mathrm{~min}$ at $5000 \mathrm{~g}$ and $1 \mathrm{ml}$ of the supernatant was withdrawn and counted for radioactivity. All determinations were carried out in triplicates. The relative binding affinities of the steroids for cytosolic glucocorticoid receptors were determined as described by Ojasoo \& Raynaud (10). The relative binding affinity of dexamethasone was taken to be equal to 100 .

\section{$\left[{ }^{3} H\right]$ Thymidine incorporation assay}

Peripheral blood lymphocytes from healthy donors were isolated using a Ficoll Hypaque double gradient technique (11). The cells were washed three times in Hanks balanced salt solution and resuspended at a all concentration of $10^{9} / 1$ cells in medium 199 (Flow Laboratories, Meckenheim, F.R.G.) supplemented with 50 $\mathrm{ml} / \mathrm{l}$ heat-inactivated human serum (blood group AB), $2 \mathrm{mmol} / \mathrm{l}$ L-glutamine, $100 \mathrm{U} / \mathrm{ml}$ penicillin and $100 \mathrm{mg} / \mathrm{l}$ streptomycin. More than $95 \%$ of the lymphocytes were viable as determined by trypan blue exclusion. Culture medium $(200 \mu \mathrm{l})$, containing $2 \times$ $10^{5}$ cells, was added to each well of round bottomed microtiter plates, followed by the addition of $10 \mu$ of phytohaemagglutinin (from Phaseolus vulgaris Type V, Difco Laboratories, Detroit, Michigan, USA) (final concentration of phytohaemagglutinin 10 $\mathrm{mg} / \mathrm{l}$ ) and $10 \mu \mathrm{l}$ of steroid solution (increasing concentrations dissolved in $0.15 \mathrm{~mol} / 1 \mathrm{NaCl}$ solution). The plates were incubated for $72 \mathrm{~h}$ at $37^{\circ} \mathrm{C}$ in a humidified atmosphere of $0.5 \mathrm{CO}_{2}$ and 0.95 air. Lymphocyte stimulation was assessed by the incorporation of $\left[{ }^{3} \mathrm{H}\right]$ thymidine into the DNA during the last $4 \mathrm{~h}$ of culture (37 $\mathrm{MBq} / \mathrm{ml})(11-13)$.

Steroid metabolism in the cultures was examined by incubation $\left[{ }^{3} \mathrm{H}\right]$ dexamethasone or carboxamide $\left[{ }^{3} \mathrm{H}\right] \mathrm{le}$ at a final concentration of $6.4 \mu \mathrm{mol} / \mathrm{l}$ with $2 \mathrm{ml}$ of cultured peripheral blood lymphocytes as described above. Radioaçtivity was at least $1 \mathrm{MBq} / \mathrm{l}$ culture mixture. After $72 \mathrm{~h}$ the cells were centrifuged and the supernatant culture medium was saved. The pellet was washed with phosphate-buffered saline and homogenized in $1 \mathrm{ml}$ of the same buffer by 10 strokes in a Potter-Elvehjem homogenizer. Both the culture medium and the homogenate were extracted twice with two volumes of methylene chloride. The organic phase.was evaporated to dryness under a stream of nitrogen and the steroids were chromatographed in solvent system (A) together with non-radioactive standards. The radioactivity spots were, scraped off the thin-layer plates and counted for radioactivity. Steroid metabolism in rat liver homogenates was examined as described (14).

\section{Assay of receptor binding to DNA-cellulose}

Cystosol fractions were incubated with $32 \mathrm{nmol} / 1\left[{ }^{3} \mathrm{H}\right]$ steroid alone or with a 1000 -fold excess of the respective unlabeled steroid for $2 \mathrm{~h}$ at $4^{\circ} \mathrm{C}$. Subsequent activation of the steroid receptor complex was accomplished by heating the cytosols at $25^{\circ} \mathrm{C}$ for $30 \mathrm{~min}$.
The procedure of Kalimi et al. (15) was used to assay the amount of receptor binding to DNA-cellulose. Activated receptor complex $(100 \mu \mathrm{l})$ was incubated with the pellet from $200 \mu \mathrm{l}$ of a $25 \%$ slurry of DNA-cellulose. The suspension was gently mixed on a Vortex homogenizer and incubated for $45 \mathrm{~min}$ at $4{ }^{\circ} \mathrm{C}$. The reaction was stopped by the addition of $2 \mathrm{ml}$ of cold buffer and centrifuged for $10 \mathrm{~min}$ at $2000 \mathrm{~g}$. The samples were then washed three times in cold buffer and the final pellet resuspended in $0.8 \mathrm{ml}$ of the buffer. A $0.5 \mathrm{ml}$ aliquot was taken for determination of radioactivity.

\section{Results}

\section{Competition studies}

The relative binding affinities of the steroids to the glucocorticoid receptors of human spleen tumours and rat liver are listed in table 2 . The $17 \beta$-carboxylic acid compounds Ia and IIa did not compete significantly for $\left[{ }^{3} \mathrm{H}\right]$ dexamethasone binding in human spleen or in rat liver tissue cytosols.

Tab. 2. Effect of substitutions in the steroid molecule on receptor binding and glucocorticoid activity.

\begin{tabular}{|c|c|c|c|}
\hline \multirow[t]{2}{*}{ Compound } & \multicolumn{2}{|c|}{$\begin{array}{l}\text { Relative binding } \\
\text { affinities }^{\mathrm{a}}\end{array}$} & \multirow{2}{*}{$\begin{array}{l}\text { Inhibition of } \\
{\left[{ }^{3} \mathrm{H}\right] \text { thymidine }} \\
\text { incorporation } \\
(\%) \text { at } \\
5 \times 10^{-6} \mathrm{~mol} / \mathrm{l} \\
\text { steroid }\end{array}$} \\
\hline & $\begin{array}{l}\text { Human spleen } \\
\text { tumour } \\
\text { leukocytes }\end{array}$ & Rat liver & \\
\hline \multicolumn{4}{|l|}{ Dexamethasone } \\
\hline (I) & 100 & 100 & 100 \\
\hline Ia & 0.1 & 0.1 & 0 \\
\hline Ib & 0.9 & 0.4 & 10 \\
\hline Ic & 12 & 9 & 70 \\
\hline Id & 0.7 & 0.3 & 15 \\
\hline Ie & 27 & 34 & 85 \\
\hline If & 9 & 8 & 60 \\
\hline Ig & 3.2 & 1.4 & 50 \\
\hline \multicolumn{4}{|l|}{ Betamethasone } \\
\hline (II) & 100 & 100 & 100 \\
\hline IIa & 0.1 & 0.1 & 0 \\
\hline IIb & 0.1 & 0.1 & 0 \\
\hline Hydrocortisone & 50 & 40 & 100 \\
\hline
\end{tabular}

a Human spleen tumour and rat liver cytosols were incubated with $32 \mathrm{nmol} / 1$ of $\left[{ }^{3} \mathrm{H}\right]$ dexamethasone either alone or in the presence of various concentrations of competitors for $4 \mathrm{~h}$ at $0{ }^{\circ} \mathrm{C}$. The unbound steroid was removed with dextran-coated charcoal. The relative binding affinity values listed are means of three determinations.

b Lymphocytes were isolated as described. Phytohaemagglutinin and increasing amounts of steroids were added followed by $72 \mathrm{~h}$ of incubation. Lymphocyte stimulation was assessed by the incorporation of $\left[{ }^{3} \mathrm{H}\right]$ thymidine into the DNA during the last $4 \mathrm{~h}$ of culture. Similar results were found in peripheral blood lymphocytes of different donors. In this particular experiment the mean background was $10 \mathrm{~min}^{-1}$, and the mean maximal incorporation corresponded to $336 \mathrm{~min}^{-1}$. 
Amidation partly restored the binding capacity with the exception of amide IIb. Representative competition curves are shown in figure 1 . None of the fluorinated derivatives bound to corticosteroid binding globulin (data not shown).

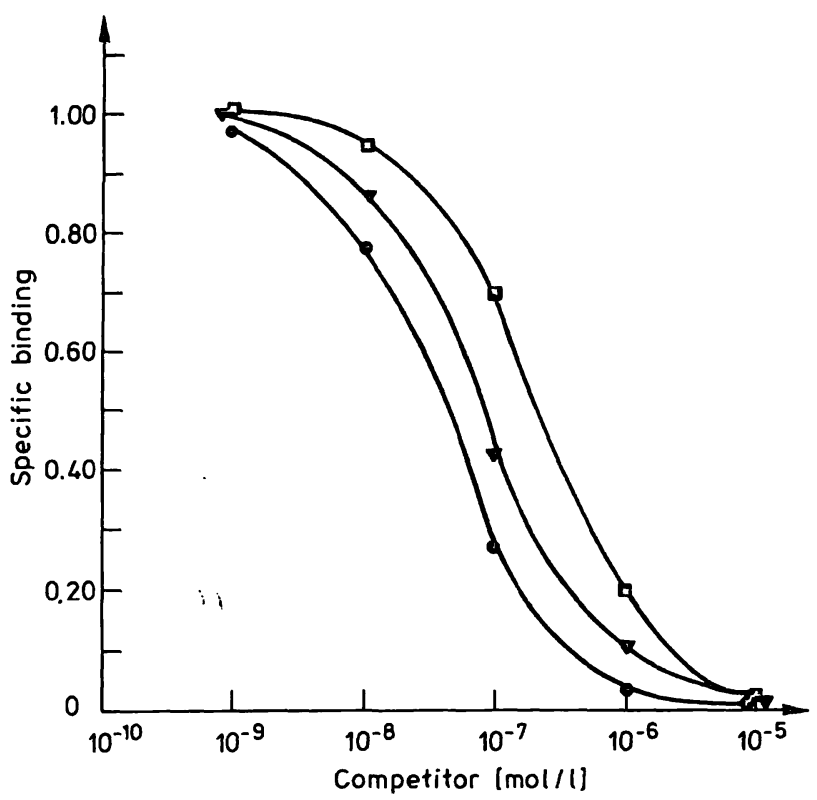

Fig. 1. Competition of various steroids for glucocorticoid receptors in human spleen tumour cytosol. Cytosol was incubated with $32 \mathrm{nmol} / 1\left[{ }^{3} \mathrm{H}\right]$ dexamethasone \pm competitors for $4 \mathrm{~h}$ at $0{ }^{\circ} \mathrm{C}$ and specific binding determined. Total specific binding in the absence of competitor was taken as $100 \%$. The symbols are: 0 dexamethasone (I), $\nabla$ hydrocortisone, - 17ß-carboxamide (Ie).

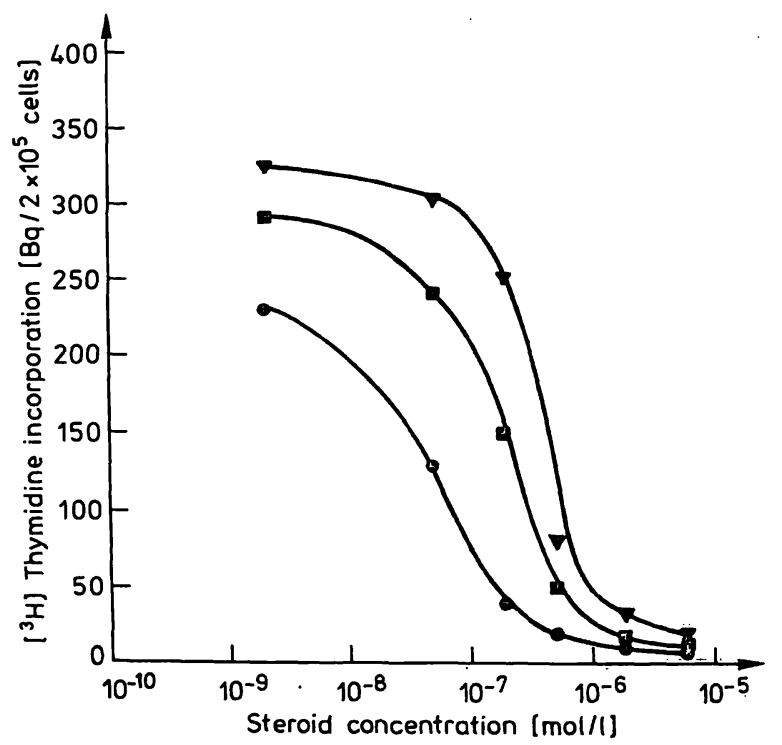

Fig. 2. Effect of various steroids on $\left[{ }^{3} \mathrm{H}\right]$ thymidine incorporation in human peripheral blood lymphocytes. Lymphocytes were isolated as described. Phytohaemagglutinin and increasing concentrations of steroids were added and the cells incubated for $72 \mathrm{~h}$ at $37^{\circ} \mathrm{C}$. Stimulation was assessed by the incorporation of $\left[{ }^{3} \mathrm{H}\right]$ thymidine into the DNA during the last $4 \mathrm{~h}$ of culture. The symbols are: dexamethasone (I), $\nabla$ hydrocortisone, $⿴$ 17 $\beta$-carboxamide (Ie).
Inhibition of phytohaemagglutinin-mediated blastogenesis of normal human peripheral blood lymphocytes

The inhibition of $\left[{ }^{3} \mathrm{H}\right]$ thymidine incorporation in phytohaemagglutinin-stimulated peripheral blood lymphocytes by dexamethasone, 'betamethasone and their analogues is shown in table 2. The order of inhibition closely resembles that of the binding affinities to the spleen tumour receptors (fig. 1 and fig. 2), and is similar for different concentrations of phytohaemagglutinin and concanavalin $\mathrm{A}$ (i.e. for different levels of stimulation) (fig. 3a, b).

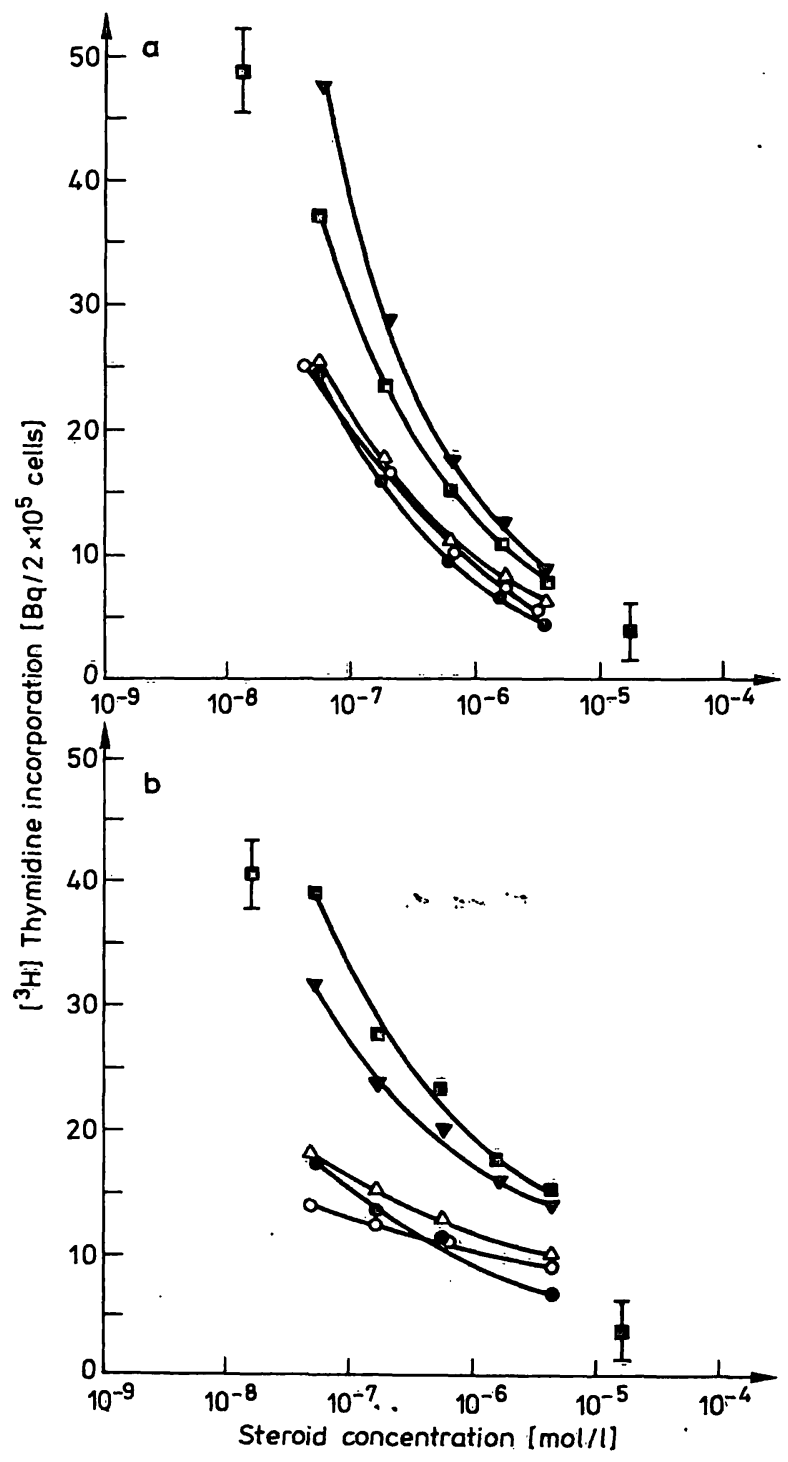

Fig. 3. Effect of various steroids on $\left[{ }^{3} \mathrm{H}\right]$ thymidine incorporation in differently stimulated human peripheral blood lymphocytes. Lymphocytes were isolated as described and the cell count was adjusted to $2 \times 10^{5}$ cells per culture volume $(200 \mu)$. Phytohaemagglutinin (fig. 3a; final concentration $1.25 \mathrm{mg} / \mathrm{l}$ ) or concanavalin A (fig. $3 \mathrm{~b}$; final concentration $2.5 \mathrm{mg} / \mathrm{l}$ solutions $(10 \mu \mathrm{l})$ and steroid solutions $(10 \mu \mathrm{l})$ of increasing concentrations were added and the cells incubated for $72 \mathrm{~h}$ at $37^{\circ} \mathrm{C}$. Stimulation was assessed by the incorporation of $\left[{ }^{3} \mathrm{H}\right]$ thymidine into the DNA during the last $4 \mathrm{~h}$ of culture. The symbols are: dexamethasone (I), $\odot$ betamethasone (II); $\Delta$ desoxymethasone, $\nabla$ hydrocortisone, 17 $\beta$-carboxamide (Ie). 
The original cell number did not significantly change within the first 3 days of culture and there was no hint that the survival of peripheral blood lymphocytes was negatively affected by any of the steroids used in this study. In addition, no significant metabolic conversion of carboxamide $\left[{ }^{3} \mathrm{H}\right]$ le by cultured lymphocytes or rat liver cytosols was observed.

\section{DNA-cellulose binding of non-activated glucocorti- coid-receptor complex}

Cytosols were either labeled with $\left[{ }^{3} \mathrm{H}\right]$ dexamethasone or carboxamide $\left[{ }^{3} \mathrm{H}\right] \mathrm{le}$ and heat activated $\left(25^{\circ} \mathrm{C}\right.$ for $\left.45 \mathrm{~min}\right)$. Bound radioactivity and DNAcellulose binding were then determined (tab. 3). Under our experimental conditions, it appeared that only human spleen tumour glucocorticoid receptors were able to form activated carboxamide $\left[{ }^{3} \mathrm{H}\right] \mathrm{Ie}$-receptor complexes, whereas in the presence of 10 mmol/l $\mathrm{Na}_{2} \mathrm{MoO}_{4}$ neither $\left[{ }^{3} \mathrm{H}\right]$ dexamethasone nor carboxamide $\left[{ }^{3} \mathrm{H}\right] \mathrm{Ie}$-receptor complexes were activated by heat treatment.

\section{Discussion}

Antagonists of hormone action may exert their effect by interfering with the synthesis or metabolism of a specific or any of the proteins that are essential to the expression of that steroid's physiological response (2). Some antagonists act by direct competition for the hormone binding site on the receptor ( 1 , $16,17)$. In these cases it would be of inestimable value for the organic chemist to identify which structural features control agonist and antagonist responses.

$\mathrm{X}$-ray crystal structure studies on dexamethasone and the possible glucocorticoid antagonist dexamethasone oxetanone (2) showed that both agonist and antagonist can accept a hydrogen bond to the oxygen atom at the $\mathrm{C}-20$ position of the steroid skeleton, whereas only the agonist can also donate two hydrogen bonds to effect or stabilize a receptor interaction. Thus the lack of induction of tyrosine aminotransferase in cultured rat hepatoma cells by $17 \beta$ carboxamide steroids, as well as their potency as antagonists of the action of dexamethasone on these cells (1), might be explained by the lack of receptor stabilizing hydrogen bond donors in the carboxamide side-chain.

This hypothesis, however, is only applicable to rat liver (5) or rat liver derived cells, as the same derivatives may also behave like glucocorticoid agonists by
Tab. 3. DNA-Ccllulose binding of non-activated and activated glucocorticoid-receptor complexes.

Human spleen tumour or rat liver cytosols were labelled with either $\left[{ }^{3} \mathrm{H}\right]$ dexamethasone or carboxamide $\left[{ }^{3} \mathrm{H}\right] \mathrm{Ic}$ and heat activated for $45 \mathrm{~min}$ at $25^{\circ} \mathrm{C}$. Aliquots were assayed for DNA-cellulose binding and bound radioactivity prior to and after heat activation. The values listed are means of three determinations.

\begin{tabular}{|c|c|c|c|c|}
\hline \multirow{3}{*}{ Compound } & \multicolumn{4}{|c|}{$\%$ bound DNA-cellulose $\mathrm{e}^{\mathrm{a}}$} \\
\hline & \multicolumn{2}{|c|}{$\begin{array}{l}\text { Human spleen } \\
\text { Heat activation }\end{array}$} & \multicolumn{2}{|c|}{$\begin{array}{l}\text { Rat liver } \\
\text { Heat activation }\end{array}$} \\
\hline & prior & after & prior & after \\
\hline$\left[{ }^{3} \mathrm{H}\right]$ Dexamethasone & 2.5 & 10.0 & 5.6 & 23.0 \\
\hline $\begin{array}{l}{\left[{ }^{3} \mathrm{H}\right] \text { Dexamethasone }} \\
+10 \mathrm{mmol} / 1 \mathrm{Na}_{2} \mathrm{MoO}_{4}\end{array}$ & 2.2 & 2.1 & 2.0 & 1.8 \\
\hline$\left[{ }^{3} \mathrm{H}\right] \mathrm{le}$ carboxamide & 1.6 & 10.0 & 3.0 & 3.1 \\
\hline $\begin{array}{l}{\left[{ }^{3} \mathrm{H}\right] \mathrm{le} \text { carboxamide }} \\
+10 \mathrm{mmol} / \mathrm{I} \mathrm{Na}_{2} \mathrm{MoO}_{4}\end{array}$ & 1.8 & 2.0 & 1.8 & 2.1 \\
\hline
\end{tabular}

a (DNA-cellulose binding) / (total cytoplasmic ${ }^{3} \mathrm{H}$-steroid binding) $\times 100$ (23).

inhibiting the mitogen-induced blastogenesis of human peripheral blood lymphocytes (tab. 2 and fig. 2). As no chemical alteration of carboxamide Ie could be detected during its incubation with cultured lymphocytes, the quite unlikely transformation of original antagonists to agonists, followed by an agonist-typical response (i.e. similarity of the order of magnitude of inhibition potency and binding affinity) of the lymphocytes $(4,7)$, can definitely be excluded. The divergent behaviour in the special case of carboxamide IIb is discussed elsewhere (7).

Structural details undoubtedly have a direct bearing upon receptor affinity and will directly or indirectly influence receptor activation, transport and nuclear interaction (18). It has been shown that activation increases the affinity of steroid-receptor complexes not only towards nuclei, but also towards various polyanions (19) and calf-thymus DNA immobilized on cellulose (15). We have therefore used a DNA-cellulose assay to further investigate whether the double nature of these carboxamide steroids might reflect differences in the activability of carboxamidereceptor complexes of both tissues. Our results indicate that carboxamide Ie, which binds to both receptors with high affinity, might bei either unable to form activable complexes with rat liver glucocorticoid receptors (tab. 3) or leads to activated but labile carboxamide-receptor complexes. The latter effect 
could possibly explain the weak agonistic activity of some $17 \beta$-carboxamide steroids on tyrosine aminotransferase induction in cultured rat hepatoma cells (1).

The low amount of heat-activable spleen tumour receptors might be the consequence of the unfavourable protein-receptor ratio in these cytosols (livers of adrenalectomized rats contain $\sim 900 \mathrm{fmol}$ receptor per $\mathrm{mg}$ protein, human spleen tumours $\sim 80 \mathrm{fmol}$ receptors per mg protein (14)). Heat activation of all complexes could be inhibited by the presence of 10 $\mathrm{mmol} / \mathrm{l} \mathrm{Na}_{2} \mathrm{MoO}_{4}$ in the homogenisation buffer (20).

It was previously proposed (2) that the steroid A ring might be primarily responsible for initiating and maintaining hormone binding to the receptors while the D-ring might control expression of activity. This hypothesis, however, assumes that the hormone binding sites of glucocorticoid receptors of different species are at least similar (21). On the contrary, we maintain, on the basis of the literature $(16,17,22)$ and our own results (7), that a generalized rationale of structure-activity relationships for glucocorticoid hormones is at the moment impossible.

\section{Acknowledgement}

We would like to thank Miss $U$. Pfeffer for her technical assistance.

\section{References}

1. Rousseau, G. G.', Kirchhoff, J., Formstecher, P. \& Lustenberger, P. (1979) Nature 279, 158-160.

2. Duax, W. L., Griffin, J. F., Rohrer, D. C. \& Wecks, C. M. (1982) In: Hormone Antagonists (Agarwal, M. K., ed.) Walter de Gruyter, Berlin.

3. Baxter, J. D. \& Rousseau, G. G. (1979) In: Glucocorticoid Hormone Action (Baxter, J. D. \& Rousseau, G. G., eds.) Springer Verlag, Berlin, Heidelberg, New York.

4. Lippman, M. E. (1979) In: Glucocorticoid Hormone Action (Baxter, J. D. \& Rousseau, G. G., eds.) Springer Verlag, Berlin, Heidelberg, New York.

5. Manz, B. \& Govindan, M. V. (1979) Cancer Treat. Rep. 63, 1158.

6. Manz, B., Kreienberg, R., Grill, H.-J. \& Pollow, K. (1982) Acta Endocrinol. Suppl. 246, 156- 157.

7. Manz, B., Grill, H.-J., Kreienberg, R., Rehder, M., Köhler, I. \& Pollow, K. (1983) J. Clin. Chem. Biochem. 21, 69-75.

8. Formstecher, P., Lustenberger, P. \& Dautrevaux, M. (1980) Steroids 35, 265-272.

9. Manz, B., Heubner, A., Köhler, I., Grill, H.-J. \& Pollow, K. (1983) Eur. J. Biochem. 131, 333-338.

10. Ojasoo, T. \& Raynaud, J.-P. (1978) Cancer Res. 38, 4186-4198.

11. Agnado, M. T., Pujd, N. Rubiol, E., Tura, M. \& Celado, A. (1980) J. Immunol. Methods 32, 41-50.

12. Stewart, C. C., Cramer, S. F. \& Steward, P. G. (1975) Cell Immunol. 16, 237-250.

13. Berger, N. A., Berger, S. J., Sikorski, G. W. \& Catino, D. M. (1982) Exp. Cell Res. 137, 79-88.

14. Manz, B., Grill, H.-J. \& Pollow, K. (1982) J. Steroid Biochem. 17, 335-342.

15. Kalimi, M., Colman, P. \& Feigelson, P. (1975) J. Biol. Chem. 250, 1080-1086.

16. Raynaud, J.-P., Bonne, C., Bouton, M. M., Moguilewsky, M. Philibert, O. \& Azadian-Boullanger, G. (1975) J. Steroid Biochem. 6, 615-622.

17. Rousseau, G. G. \& Schmit, J.-P. (1977) J. Steroid Biochem. 8, 911-919.

18. Lee, H. J., Bradlow, H. L., Moran, M. C. \& Sherman, M. R. (1981) J. Steroid Biochem. 14, 1325-1335.

19. Bailly, A., Savouret, J.-F., Sallas, N. \& Milgrom, E. (1978) Eur. J. Biochem. 88, 623-632.

20. Leach, K. L., Dahmer, M. K., Hammond, N. D., Sando, J. J. \& Pratt, W. B. (1979) J. Biol. Chem. 254, 11884-11890.

21. Feldman, D., Funder, J. \& Loose, D. (1978) J. Steroid Biochem. 9, 141-145.

22. Kontula, K., Jänne, O., Vihko, R., Evert de Jager, Jacob de Visser \& Zeelen, F. (1975) Acta Endocrinol. 78, 574-592.

23. Sekula, B. C., Schmidt, T. J., Oxenham, E. A., DiSorbo, D. M. \& Litwack, G (1982) Biochemistry 21, 2915-2922.

\section{Dr. B. Manz}

Abteilung für Experimentelle Endokrinologie

Universitätsfrauenklinik

Johannes Gutenberg Universität

Langenbeckstr. 1

D-6500 Mainz 1 